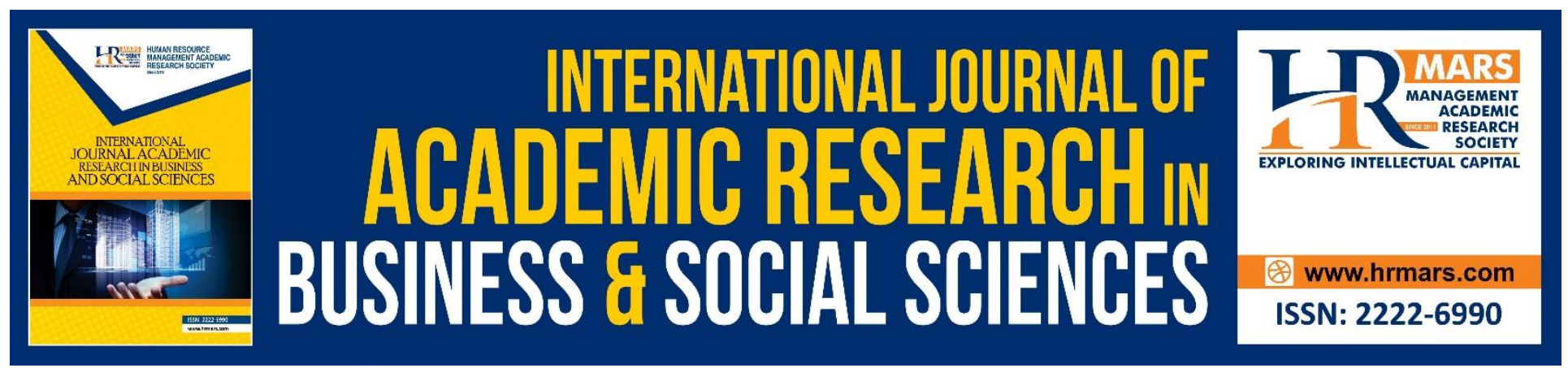

\title{
Influence of Stakeholders Involvement on Development Project Performance in Guinea
}

Sekou Marouf Magassouba, Abdul Malek Bin A. Tambi, Baker Ibrahim Alkhlaifat, Abdul Aziz Bin Abdullah

To Link this Article: http://dx.doi.org/10.6007/IJARBSS/v9-i1/5513 DOI: $10.6007 /$ IJARBSS/v9-i1/5513

Received: 09 Dec 2018, Revised: 05 Jan 2019, Accepted: 22 Jan 2019

Published Online: 29 Jan 2019

In-Text Citation: (Magassouba, Tambi, Alkhlaifat, \& Abdullah, 2019)

To Cite this Article: Magassouba, S. M., Tambi, A. M. B. A., Alkhlaifat, B. I., \& Abdullah, A. A. Bin. (2019). Influence of Stakeholders Involvement on Development Project Performance in Guinea. International Journal of Academic Research in Business and Social Sciences, 9(1), 1111-1120.

Copyright: (C) 2019 The Author(s)

Published by Human Resource Management Academic Research Society (www.hrmars.com)

This article is published under the Creative Commons Attribution (CC BY 4.0) license. Anyone may reproduce, distribute, translate and create derivative works of this article (for both commercial and non-commercial purposes), subject to full attribution to the original publication and authors. The full terms of this license may be seen

at: http://creativecommons.org/licences/by/4.0/legalcode

Vol. 9, No. 1, 2019, Pg. 1111 - 1120

http://hrmars.com/index.php/pages/detail/IJARBSS

JOURNAL HOMEPAGE

Full Terms \& Conditions of access and use can be found at http://hrmars.com/index.php/pages/detail/publication-ethics 


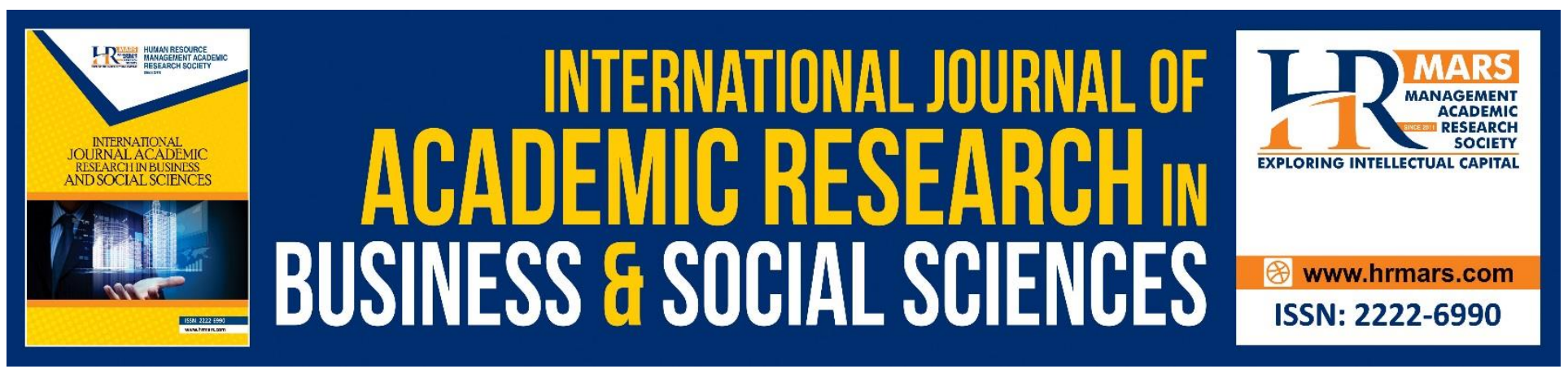

\title{
Influence of Stakeholders Involvement on Development Project Performance in Guinea
}

\author{
Sekou Marouf Magassouba \\ Faculty of Economics and Management Sciences, Universiti Sultan Zainal Abidin \\ Email : Maroufmagass@gmail.com \\ Prof. Dr. Abdul Malek Bin A. Tambi \\ Faculty of Economics and Management Sciences, Universiti Sultan Zainal Abidin \\ Email : Malekahmad@yahoo.com \\ Baker Ibrahim Alkhlaifat \\ Faculty of Economics and Management Sciences, Universiti Sultan Zainal Abidin \\ Email : Bakerkhlifat@hotmail.com

\section{Prof. Dr. Abdul Aziz Bin Abdullah} \\ Faculty of Economics and Management Sciences, Universiti Sultan Zainal Abidin \\ Email : Abdulazizum@gmail.com
}

\begin{abstract}
Stakeholder involvement plays an important and critical role in project performance. In Guinea, the Administration and Control of Major Projects and Public Procurement (ACMPPP) has initiated a huge reforms and reorganizations of development projects implementation since 2014. This has involved different stakeholders who include: the Government through the operating Ministries, International Institutions such as United Nations Development Program, World Bank, Africa Development Bank etc., Construction and Manufacturing Companies as well as NonGovernmental Organizations. This paper will examine the literature around the stakeholders' involvement concepts to address their influence in project identification, planning, implementation and monitoring on development project performance within organizations in Guinea.
\end{abstract}

Key words: Stakeholder Involvement, Development Project, Project Performance, Guinea.

\section{INTRODUCTION}

It has been mentioned by earlier project management scholars that stakeholder involvement is critical success factor for every project within any organization. Development projects are a major 
contributors to countries' development and the participation of different stakeholders to ensure that performance is fundamental and capital. Hence, in a development project context, the number of stakeholder is generally large and can vary significantly in the degree of influence. Mitchell et al., (1997) identified the power, legitimacy and urgency as the key stakeholder characteristics. The nature and number of stakeholders will be determined according to the type, size of projects and it would therefore make sense to carry out the review of their identification throughout the project implementation Moodley (2002).

Project managers are always deploying many efforts and resources to complete their projects successfully. This involves completing the project on time, within budget, meeting product specifications etc. specifically, despite the quest for project success, development projects in Guinea have continuously experienced cost and time overrun, poor quality performance unmet product specifications, unsatisfactory of stakeholders needs and requirements and unmet of organization objectives.

Moreover, stakeholder involvement can take different level and forms during the project execution. This can line up along with the project predefinition and initiation requirements, the organization strategic objectives through negotiation, consultation, partnership and project final goal. Stakeholder involvement is both a means and an end. As a means, it is a process in which people and communities cooperate and collaborate in developing the project.

A wide number of researchers depicted stakeholder involvement as a potential contributor to project success (Freeman, 1984; Boonstra, 2006; Achterkamp and Vos, 2008; Adrienne Watt, 2014). The predominant idea behind that has been oriented in understanding the extent of stakeholders' contribution on project performance within organizations (Rabe and Betsil, 2009). Further, involvement of stakeholder in project is a valuable concern for project managers to address the time, costs and quality constraints associated with project portfolio management. Therefore, for a project managers, to carry out a successful projects and to meet users' and organization requirement, stakeholder involvement and satisfaction is the key to determine whether a project fails or succeeds. In conclusion, stakeholder involvement is actually more important than ever because of the "interconnected" nature of project activities (Bryson, 2013). Any project be economic, social, educational, environmental needs an active commitment of all its stakeholders (Freeman and Beale, 1992). Thus development projects require participatory approach of stakeholders in identifying and solving problems affecting project implementation (Boonstra, 2006; Achterkamp and Vos, 2008; Adrienne Watt, 2014).

\section{LITERATURE REVIEW}

\section{Project Performance}

The ultimate performance of project is achieved through keeping it within the allocated budget, time, scope and meeting the required technical standards for quality, operations, functionality, safety and environment protection (Flanagan and Norman 2003). Project performance ensures that organizations, maximize on profitability and minimize the consequences of risks and uncertainties events in terms of achieving the project's objectives (Kululanga and Kuotcha, 2010).

According to Mohammed (2002), the basic components and criteria to measure project performance are cost, time, scope and quality which are also largely accepted by project management previous 
reviewers. For instance, project quality constitutes the primary requisite when it comes to evaluate the project acceptance by customers. To ensure the conformity and effectiveness of quality performance, the specification of quality requirements should be clearly and explicitly stated in planning and contract documents. Project performance indicators for this study will be defined in terms of cost, time, quality, scope and profitability, as many organizations expect to earn returns on project invested capital. In Guinea, project performance, frequently has been assessed through project cost, quality, users' satisfaction, timeliness and achieving project overall objective and those factors are considered as an effective indicator to measure project success (Pinto and Slevin, 1987; Cleland, 1999).

Lekunze, (2001) conducted a study on stakeholder involvement in integrated water resource management in community water management projects in Cameroon. The study analyzed the commitment of youth to water resource management by comparing the results of the different approaches used. The study revealed that the organizations that practiced a stakeholder participatory approach while involving the youth had greater chances to succeed than others that did not consider as an approach.

On the other hand, Atiibo (2012) examined stakeholder management challenges and their influence on project management in the case of advocacy and empowerment in the upper east region of Ghana. The study indicated that the roles and interests of the key stakeholders were very critical to the project operations. However, stakeholder management was found to be characterized by casual and temporary actions which is not predominantly institutionalized. Challenges like unfair competition, conflict of interests, weak commitment, and poor communication line, limited expertise of managers, misunderstanding and appreciation of leadership problems were found to impact severely on the work of the organizations.

Furthermore, Menoka, (2014) did a study on stakeholder involvement and sustainability related to project performance in construction. The study sought to improve stakeholder involvement in construction project performance through achieving construction sustainability. A framework was developed and include different stakeholders with sustainability driven project performance. The research was conducted as an empirical investigation and the findings depicted that effective preparation and presentation of stakeholder involvement contributes to improve the construction project performance through achieving the construction sustainability. The study found also that there is variation of perception of projects participants' roles, stakeholder involvement, and construction sustainability and construction project performance towards organizations. This implied that involvement can be valuable in anticipating the expectations of different stakeholders from the projects.

Finally, stakeholder involvement is often dependent on the characteristics of the project and type of organization. Many studies suggest to undertake stakeholder management processes in accordance with a standardized methodology and scholars strongly advocate the central role of stakeholder involvement in delivering successful projects (O'Halloran and Menoka, 2014).

\section{Stakeholder Involvement and Development Projects}

This section presents the review related to stakeholder involvement and performance of development projects. It will be based on the research variables. 


\section{Stakeholder Involvement in Project Identification and Project Performance}

First of all, project stakeholders are groups, individuals or organizations that are actively involved in a project or whose have a vested interests in project execution, completion or results and may as well exert influence over the project objectives and outcomes. Stakeholders have a stake in the outcome of the project. It could be an interest, a right or ownership. Rights can either be legal or moral ownership in a circumstance (Carol, Cohen and Palmer, 2004).Stakeholders take advantage for having their expectations understood and managed through appropriate open communication line on one hand and ensuring that the stakeholders understand and provide support to the project on the other hand.

Moreover, the initiation processes define and determine the scope and the nature of the project. If this phase is not performed well, the project success will be probably compromised in meeting the community expectations (Nijkamp et al., 2002). The particular key project identification needed here is an understanding of the project environment and making sure that all necessary requirements and technical specifications are integrated into the project. According to Albert (2004) any inadequacies or issues should be identified, reported and a recommendation should be made to fix them. The initiation stage as the starting point of project implementation should include a plan that encompasses the following activities: selection of the best given project corresponding to the need of the community or organization, recognizing the benefit of the project, assigning project manager, defining the needs and requirements into realistic goals, financial, social and economic analysis of the costs and benefits, identifying source of funding, stakeholders analysis which include project team support, project chart, costs, tasks, deliverables and schedule etc.

Legitimate and valid stakeholders need to be identified and their power, proximity and influence understood to deal with their potential impact on the project (Curley, Steve and Ricky, 2006). Identification of stakeholders is a part of the project execution process, and consists of assigning individuals and groups whose are affected by the project or used it. Adequate and appropriate strategies can then be designed and implemented to enhance the positive influence of stakeholders. This becomes a fundamental risk management issue for project managers and failing to establish a comprehensive connection between risks related to project and stakeholder's involvement will led likely to project failure (Malunga and Banda, 2004).

\section{Stakeholder Involvement in Project Planning and Project Performance}

Stakeholder involvement in project planning activities involves definition of the project's work requirements, quality and objective, the specification of resources needed and their allocation, the definition of schedule, evaluation of various risk and determination of delivering methods. The advantage of stakeholder involvement during the planning stage allows project managers to strengthening project implementation process or it outcome.

Furthermore, Nobeoka and Cusumano (1995) did a study in Japan to determine the relationship between stakeholder involvement in project planning processes and their impact on project performance. They found that stakeholder involvement affect project goals during the planning phase, resource allocation, tasks specification and, in turn project performance. Harold (2003) suggests that stakeholder involvement in planning contributes to understand the place and roles of stakeholders in determining how to plan, developing the milestones, scope statement, assigning the 
planning team, identifying deliverables, creating the work breakdown structure (WBS), estimating the required resources for the activities, developing schedule, estimating time and cost necessary for activities, risk planning, getting formal approval to start work (Rosario, 2000).

In Addition, critical process as project planning, identifying the roles and responsibilities of all stakeholder and maintaining a warm working relationship with them are also generally suitable for project performance. The most common techniques or tools employed in the stakeholder involvement in planning stage are project Plan and Milestones Reviews. The method consists of full commitment of different stakeholders in the planning process. At this level, the project managers prepare the project budget, set objectives to each participant and plan works (Madeeha and Imran, 2014). This role is ensured by the Administration and Control of Major Project and Public Procurement in Guinea. They advise and assist Government or organizations in preparation and management of different projects stakeholder. There are other operating departments which approve project budget, schedule and work plan in their respective fields. Finally, the logic behind of engaging stakeholders in planning stage is to deliver successful and sustainable projects through identifying, analyzing, scheduling, coordinating, controlling every factor that could influence project performance.

\section{Stakeholder Involvement in Project Implementation and Project Performance}

Stakeholder involvement in project implementation is one of the most important exercise in managing projects. Project managers during the implementation stage facilitate the coordination of people, efficient utilization of resources and effective evaluation of risks to carry out the established project plan. For instance, Duncan (1996) mentioned that stakeholder involvement in project implementation is necessary to transform the planned programs and objectives of a project into realistic well-structured tasks and activities to achieve the project goals.

The complexity of stakeholder commitment in project implementation is pertaining to the characteristics of project which include for example a long duration, huge investment and many unforeseen and emergent factors (Chang, 2013). Several ways are suggested to categorize the risks and issues associated with stakeholder involvement in project implementation and project performance. Some examples are relating to project sponsorship development, business environment, government regulations, political influence, financial feasibility, procurement and social acceptability (Floricel and Miller, 2001)

According to Low Sui et al., (1996), the performance of development project is largely depending on the attitudes of different stakeholders. Hence, during the implementation, if key stakeholders of the project are not committed to adequately execute their responsibilities, it will adversely impact the overall project performance. Deming, 1986 and Joaquin et al., (2010) mentioned that the stakeholder's participation is highly important to project success, and therefore taking account their claims and interests during the project implementation stages is largely required to achieve project objectives.

Furthermore, it should be noted that, the association between projects and stakeholders involvement has a bilateral effect. In other words, while stakeholders can exert some influence on project performance, a development projects can in some extent affect stakeholders. For example, implementing a higher standard projects in construction or mining sector can improve and change 
people's living conditions but the pollution and destruction of the environment will reveal the negative effects of the project on some stakeholders (Olander, 2002; Olander and Landin, 2005a). In addition, as reported by Atkin and Skitmore (2008), practicing an appropriate stakeholder involvement approach in project implementation will make easier to manage their needs and anticipate risks that may have possible influence on project success.

\section{Stakeholder Involvement in Project Monitoring and Project Performance}

Project monitoring is the process of rigorous controlling, and assessment. It compares the planned works with actual results to determine the progress and performance Cleland, (1999). The process of determining the real situation of a project is called evaluation of project and this evaluation is necessary to find out if the project is being operated properly or not. The project monitoring has huge impact on project quality Coulter (2010). It is therefore necessary to provide an adequate control instrument that provides a structured and continuous information on the performance of the project. Project should be appraisal at both stages before and after its implementation. For instance, the purpose of monitoring and control is to estimate the effects of each factor and then analyze the performance of each element in the project success Bhim Chimoriya, (2014). Fayol (1949) noted that "control means seeing that everything occurs in conformity with established rule and expressed command". The specific objective is to establish a comprehensive approach for planning, sustainability and decision-making to meet project goals.

According to Flanagan and Norman, (2003), stakeholder participatory in monitoring influence development project performance as the implication of affected stakeholders in monitoring phase enhance the chance of success. It was also mentioned by Coulter (2010) that organizations play an important role in project monitoring and supervision and he found that there is a positive and strong relationship between stakeholder involvement during the monitoring stage and the impacts of those stakeholders are generally reflected on the performance of projects.

Involvement of stakeholder through monitoring and reporting in development projects contributes to identify hindrances and challenges surrounding the projects. Top management in organizations can use stakeholder involvement in monitoring as an opportunity to influence and support project success (Katiku, 2011). Hence, constructive and well-informed stakeholder in project monitoring is useful to the organizations as it will significantly improve the performance of the project.

\section{Conclusion}

Stakeholder involvement in project identification, planning, implementation and monitoring enhances the chance of project success and it is an appropriate way to achieve an organization goals. The information collected on stakeholders' involvement in previous study indicated the strong connection between project performance and various stakeholders and many authors agreed and are conducting more substantial investigations to ground those findings. Therefore, as discussed in the literature, stakeholders' involvement through identification, planning, implementation, monitoring and control contribute in a very great extent to project success. The present study indeed recommends rigorous evaluation of critical success factors highlighted in this paper along with the goals of the organization for more dynamic, innovate and effective project implementation. 
The study provided an insightful theory based on concepts of Participatory Development which lead to how various stakeholder Involvement would influence the performance of development projects within organizations. This approach described stakeholder as a powerful means of understanding the firms and its environment. Overall, the purpose of the theory is to bring government, managers, sponsors, contractors and community to find out their strategic role and place in project success. While having its origin in strategic management, stakeholder theory has been applied to many fields and presented and used in a number of ways that are quite distinct and involve different approaches, concepts and criteria of project assessment.

\section{REFRENCES}

Achterkamp, M. C., \& Vos, J. F. (2008). Investigating the use of the stakeholder notion in project management literature, a meta-analysis. International Journal of Project Management, 26(7), 749-757.

Albert, H. (2004). Handbook of Project Management Procedures. England: TTL publishing Ltd.

Alegre, J., \& Garau, J. (2010). Tourist satisfaction and dissatisfaction. Annals of tourism research, 37(1), 52-73.

Atiibo, K. A (2012). Examining Stakeholder Management Challenges and Their Impact on Project Management in the Case of Advocacy and Empowerment NGOs in the Upper East Region

of Ghana. Thesis Report.

Atkin, B., \& Skitmore, M. (2008). Stakeholder management in construction. Construction Management and Economics, 26(6), 549-552.

Betsill, M. Barry. G. Rabe (2009)." Climate Change and Multilevel Governance: The Evolving State and Local Roles." Toward sustainable communities: transition and transformations in environmental policy.

Boonstra, A. (2006): Interpreting an ERP-implementation project from a stakeholder perspective. International Journal of Project Management, 24(1), pp. 38-52.

Bryson, J. M., Quick, K. S., Slotterback, C. S., \& Crosby, B. C. (2013). Designing public participation processes. Public administration review, 73(1), 23-34.

Carol, Y., Cohen, M.W. \& Palmer, G.R. (2004). Project risk identification and management, AACE International Transactions.

Chang, Y. (2013). Performance measurement and adoption of balanced scorecards: a survey of municipal governments in the USA and Canada, International Journal of Public Sector Management, 17 No.3, pp.204-21.

Cleland \& Ireland, (2002). Project Management: Strategic Design and implementation, McGraw-

Hill Professional, USA, p210.

Cleland, D. I., \& Ireland, L. R. (1999). Project management: strategic design and implementation (Vol. 4). Singapore: McGraw-Hill.

Coulter, M. K., \& Coulter, M. K. (2002). Strategic management in action (p. 7). Upper Saddle River, NJ: Prentice Hall.

Curley, M. Steve and Ricky, (2006). Voluntary Management; Mobilization of the Community Resources, 195. 
INTERNATIONAL JOURNAL OF ACADEMIC RESEARCH IN BUSINESS AND SOCIAL SCIENCES

Vol. 9, No. 1, Jan, 2019, E-ISSN: 2222-6990 @ 2019 HRMARS

Dean Jr, J. W., \& Bowen, D. E. (1994). Management theory and total quality: improving research and practice through theory development. Academy of management review, 19(3), 392-418.

Duncan, W. R. (1996). A guide to the project management body of knowledge.

Fayol, H. (1949). General and industrial administration. NY: Pitman.

Flanagan, G. \& Norman U. (2003). Assessment and Control of project Risks. Englewood Cliffs: Prentice-Hall.

Floricel, S. \& Miller, R. (2001). Strategizing for anticipated risks and turbulence in large-scale engineering projects. International Journal of Project Management. 19, 445-455.

Freeman, M., \& Beale, P. (1992). Measuring project success. Project Management Institute.

Freeman, R. E. (1984). Strategic management: A stakeholder approach. Boston: Pitman. Latest edition Strategic Management: A Stakeholder Approach Freeman, R. E. 1994. The politics of stakeholder theory: Some future directions. Business Ethics Quarterly 4: pp. $\quad$ 409-421

Katiku, F. K. (2011). Factors influencing the rehabilitation of street children in Kisii Town; Kisii County (Doctoral dissertation, University of Nairobi, Kenya).

Kululanga, G. \& Kuotcha, W. S (2010) Measuring Project Risk Management Process For Construction Contractors With Statement Indicators Linked to Numerical Scores. Engineering, Construction and Architectural Management, 17 Issue: 4, pp.336 - 351

Lekunze, P., (2001). A critical Success Factors Model for Projects Rise in Planning and Implementation, Proceedings of the 7th European Conference on Information Systems Reports.

Madeeha, S. \& Imran, H. N. (2014).Impact of Internal Stakeholder's Engagement on Project Portfolio Management Success, it Industry in Lahore, Pakistan. Journal of Science International (Lahore), 26(4), 1777-1782.

Malunga, C. \& Banda, C., (2004).Understanding Organizational Sustainability through African Proverbs. Washington: Pact Publications.

Menoka, R. (2014) Stakeholder Engagement and Sustainability-related Project Performance in Construction. Journal of Project Management .Vol.3.

Mitchel, T.R. \& D. Daniel (2004). Motivation: In comprehensive Handbook of Psychology. Vol12. Industrial and Organizational Psychology. Ed. W.C. Borman, D.R. Ilegen, and R.J. Klimoski.

Mitchell, R., Agle, B. and Sonnenfeld, J. (1999). Who Matters to CEOs? An Investigation Stakeholder Attributes and Salience, Corporate Performance, and CEO Values. The Academy of Management Review, 22 (5), pp. 507-525. Available at: https://www.jstor.org/stable

Mohammed, A. (2002): Street Freedom. New York Publishing Press: USA, Munyakho, D. (1992):

Child New Corners in the Urban Jungle. UNICEF.

Moodley, K. (2002). Project Stakeholders, Engineering Project Management, Edited by N. J. Smith, $2^{\text {nd }} \quad$ Edition. Blackwell Publishing p. 127-136

Nijkamp, M.L. \& Tanis, C. (2002). The project System Experience - from Adoption of Success, Novartis Foundation for Sustainable Development. (2004). Development Assistance at the Threshold of the 21st Century Report. 
INTERNATIONAL JOURNAL OF ACADEMIC RESEARCH IN BUSINESS AND SOCIAL SCIENCES

Vol. 9, No. 1, Jan, 2019, E-ISSN: 2222-6990 C 2019 HRMARS

Nobeoka, K., \& Cusumano, M. A. (1995). Multiproject strategy, design transfer, and project performance: a survey of automobile development projects in the US and Japan. IEEE Transactions on Engineering Management, 42(4), 397-409.

O'Halloran, M. (2014). The Awareness of Stakeholder Management amongst Project Managers in the Construction Industry in Ireland.

Olander, S., \& Landin, A. (2005). Evaluation of stakeholder influence in the implementation of construction projects. International journal of project management, 23(4), 321-328.

Rosario, J.G. (2000). On the leading edge: Critical Success Factors in PROJECTS implementation. Journal of project management. 4 (3).

Slevin \& Pinto., (1987). Balancing Strategy and tactics in Project Implementation. Sloan Management Review 29. Vol1, pp. 33-34.

Sui Pheng, L., \& Ke-Wei, P. (1996). A framework for implementing TQM in construction. The TQM Magazine, 8(5), 39-46.

Thøgersen, J., \& Ölander, F. (2002). Human values and the emergence of a sustainable consumption pattern: A panel study. Journal of economic psychology, 23(5), 605-630.

Watt, A. (2014). Risk Management Planning. A. Watt, Project Management, 150-158. 